ZIBELINE INTERNATIONAL

ISSN: 2616-1923 (online)

RESEARCH ARTICLE

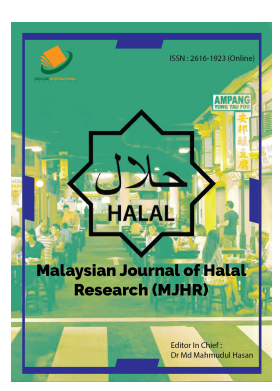

CODEN : MJHRAB

\title{
SCREENING OF LENTIL GERMPLASM AGAINST STEMPHYLIUM BLIGHT BY OBSERVING DISEASE REACTION IN THREE DIFFERENT STAGES
}

\author{
${ }^{1}$ International Maize and Wheat Improvement Center (CIMMYT)-Bangladesh \\ ${ }^{2}$ Department of Plant Pathology, Patuakhali Science and Technology University \\ ${ }^{3}$ Department of Horticulture, Patuakhali Science and Technology University \\ * To whom correspondence should be addressed. Email: md.a.razzak@cgiar.org
}

Md. Abdur Razzak ${ }^{*}$, Md. Amirul Islam¹, Md. Habibur Rahman², Maria Akter Sathi³ ${ }^{3}$ Md. Atikuzzamman ${ }^{1}$

This is an open access article distributed under the Creative Commons Attribution License, which permits unrestricted use, distribution, and reproduction in any medium, provided the original work is properly cited.

\section{ARTICLE DETAILS}

Edited by:

Md. Mahmudul Hasan, Jessore University of Science and Technology, Jessore-7408, Bangladesh.

Email: drhasan_nft@just.edu.bd

Reviewed by:

1. Engr. Mudassir arif

Department of Food engineering

University of agriculture faisalabad

mudassir.arif@uaf.edu.pk

2. Dr. Abdul Nasir

Department of structures and

environmental

University of agriculture faisalabad anawan@uaf.edu.pk

Received 10 May 2018

Revised 01 June 2018

Accepted 12 June 2018

Available online 1 July 2018

\section{ABSTRACT}

Stemphylium blight of lentil (Stemphylium botryosum) a standout amongst the most vital constraints of lentil production in Bangladesh. An investigation was carried out at the Regional Agricultural Research Station (RARS), Bangladesh Agriculture Research Institute (BARI), Rahmatpur, Barisal to pick out lentil germplasms against Stemphylium blight. Under the present study 100 lentil lines and 2 check varieties were evaluated for their reaction to Stemphylium blight and yield performance under natural epiphytotic condition at three growth stage namely flowering stage, pod setting stage and maturity stage. Altogether 102 lines/varieties were screened where 5, 91 and 6 lines were selected as Highly Resistant (HR), Resistant (R) and Moderately Resistant (MR) respectably at flowering stage. The highly resistant 5 lines were BD-3921, BD-3930, BD-3931, BARI Masur-7 and Local check. In pod setting stage, out of 102 lines/varieties, 16, 78 and 8 lines were showed Resistant (R), Moderately Resistant (MR) and Moderately Susceptible (MS) reaction, respectably, to stemphylium blight disease of lentil. During maturity, 40, 52 and10 lines out of 102 lines/varieties were expressed as Moderately Resistant (MR), Moderately Susceptible (MS) and Susceptible (S) reaction, respectively.

\section{KEYWORDS}

Stemphylium blight, Lentil, Resistant, Growth stages and Yield.

\section{INTRODUCTION}

Lentil (Lens culinaris L.) is one of aged crops in earth. This legume crop has been grown mainly to fulfill quality protein need in regular human diets, especially in Asia. This crop mainly grown in winter season under rainfed conditions in different regions of Bangladesh. Among the crops grown in Bangladesh, pulses ranks second in area (6.74 lakh ha) and third in production (7.16 lakh MT). With the mean yield of pulses is 0.89 -ton ha-1 [1]. Current production does not able to fulfill the requirement that is needed by the people of Bangladesh. That's why, it is imported in a substantial amount to meet domestic prerequisite putting enormous burden on the national exchequer [2]. The daily per capita consumption of all pulses in this country is comparatively lower (only $12 \mathrm{gm}$ ) than India (45gm) [3].

The reason behind irregular yield in lentil is the infection of several disease like Stemphylium blight, Rust and foot and root rot. Among them Stemphylium blight caused by Stemphylium sarciniformis has created panic in the lentil producers and also scientists in the country. Previous researches that conducted in Bangladesh and India assessed yield losses of $62 \%$ and total crop failure have been accounted for at times where the disease defoliated the crop in the early pod setting stage [4,5]. Infected crop debris and seed happens to be a significant sources of stemphylium inoculum. Infected crop debris can likewise turn into a fountain of primary inoculum as of air-borne ascospores or as resting mycelium. It is also known to be carried on but the purport of seed borne inoculum isn't unmistakably characterized on disease initiation in lentil [6].

It has revealed that the pathogen commences disease infection when the surrounding temperature at night stays over $8^{\circ} \mathrm{C}$; and the mean day temperature surpasses $22^{\circ} \mathrm{C}$ and in addition, canopy RH must reach $94 \%$ likewise [7]. There are many options to control the disease. Among the different alternate means of disease management, development of resistant/tolerant varieties is the most widely preferred method. To identify the resistant/tolerant source of lentil germplasms against stemphylium blight was the view of this research.

\section{MATERIALS AND METHODOLOGY}

\section{$2.1 \quad$ Experiment details}

The experiment was conducted at experimental field of Pulses Research Centre (PRC), Regional Agricultural Research Station (RARS), Bangladesh Agricultural Research Instituted (BARI), Rahmatpur, Barisal. The experiment was laid out in Randomized Complete Block Design (RCBD) with two replications. The individual plot size was $2 \mathrm{~m}^{2}(4 \mathrm{~m} \times 0.5 \mathrm{~m})$. Block to block distance was $0.5 \mathrm{~m}$. The length of each row was $4 \mathrm{~m}$ and width was $0.25 \mathrm{~m}$. BARI masur-7 and local variety was sown as check. Provax-200 @ $5 \mathrm{~g} / \mathrm{kg}$ was used to treat lentil seed to reduce seed borne pathogen. Furrows were made with power tiller driven furrows maintaining a 
distance of $40 \mathrm{~cm}$. Seeds were sown in the furrow using a polybag containing required amount for each plot. The furrows were covered with soil soon after sowing. The length of line was $4 \mathrm{~m}$ with continuous sowing of seed in the lines. All intercultural operations were followed as per BARI Handbook. The weather of the experimental site during the study period was collected from the Metrological Department. Barisal, Bangladesh.

\section{$2.2 \quad$ Plant materials}

Seeds of 100 lentil varieties/lines were collected from Plant Genetic Resource Centre (PGRC) Gazipur and Pulses Research Centre (PRC), Ishurdi, Pabna for this experiment. The collected seeds were stored in a well-ventilated room at room temperature immediately after receiving. Seeds were preserved in a refrigerator at controlled temperature in the Plant Pathology laboratory of RARS followed by registration till field experiment starts.

Table 1: Lentil lines or materials are used in this experiment

\begin{tabular}{|c|c|c|c|}
\hline $\begin{array}{l}\text { SL. } \\
\text { No. }\end{array}$ & Entry name & $\begin{array}{l}\text { SL. } \\
\text { No. }\end{array}$ & Entry name \\
\hline 1. & BD-3916 & 51 & BD-4023 \\
\hline 2. & BD-3917 & 52 & BD-4024 \\
\hline 3. & BD-3918 & 53 & BD-4026 \\
\hline 4. & BD-3920 & 54 & BD-4028 \\
\hline 5. & BD-3921 & 55 & BD-4046 \\
\hline 6. & BD-3922 & 56 & BD-4047 \\
\hline 7. & BD-3924 & 57 & BD-4049 \\
\hline 8. & BD-3925 & 58 & BD-4050 \\
\hline 9. & BD-3926 & 59 & BD-4051 \\
\hline 10. & BD-3927 & 60 & BD-4053 \\
\hline 11. & BD-3928 & 61 & BD-4054 \\
\hline 12. & BD-3929 & 62 & BD-4062 \\
\hline 13. & BD-3930 & 63 & BD-4069 \\
\hline 14. & BD-3931 & 64 & BD-4087 \\
\hline 15. & BD-3932 & 65 & BD-4088 \\
\hline 16. & BD-3936 & 66 & BD-4090 \\
\hline 17. & BD-3938 & 67 & BD-4091 \\
\hline 18. & BD-3940 & 68 & BD-4093 \\
\hline 19. & BD-3941 & 69 & BD-4094 \\
\hline 20. & BD-3943 & 70 & BD-4095 \\
\hline 21 & BD-3945 & 71 & BD-4097 \\
\hline 22 & BD-3948 & 72 & BD-4102 \\
\hline 23 & BD-3950 & 73 & BD-4105 \\
\hline 24 & BD-3961 & 74 & BD-4115 \\
\hline 25 & BD-3961 & 75 & BD-4122 \\
\hline 26 & BD-3963 & 76 & BD-4127 \\
\hline 27 & BD-3964 & 77 & BD-4130 \\
\hline 28 & BD-3965 & 78 & BD-4134 \\
\hline 29 & BD-3966 & 79 & BD-5976 \\
\hline 30 & BD-3970 & 80 & BD-5982 \\
\hline 31 & BD-3972 & 81 & BD-5983 \\
\hline 32 & BD-3974 & 82 & BD-5986 \\
\hline
\end{tabular}

\begin{tabular}{|c|c|c|c|}
\hline $\begin{array}{l}\text { SL. } \\
\text { No. }\end{array}$ & Entry name & $\begin{array}{l}\text { SL. } \\
\text { No. }\end{array}$ & Entry name \\
\hline 33 & BD-3975 & 83 & BD-5989 \\
\hline 34 & BD-3977 & 84 & BD-5991 \\
\hline 35 & BD-3978 & 85 & BD-5992 \\
\hline 36 & BD-3979 & 86 & BD-5993 \\
\hline 37 & BD-3980 & 87 & BD-5994 \\
\hline 38 & BD-3981 & 88 & BD-5996 \\
\hline 39 & BD-3983 & 89 & BD-5997 \\
\hline 40 & BD-3984 & 90 & BD-5998 \\
\hline 41 & BD-3985 & 91 & BD-6002 \\
\hline 42 & BD-3986 & 92 & BD-6007 \\
\hline 43 & BD-3987 & 93 & BD-6008 \\
\hline 44 & BD-3988 & 94 & BD-6010 \\
\hline 45 & BD-3989 & 95 & BD-6017 \\
\hline 46 & BD-3990 & 96 & BD-6018 \\
\hline 47 & BD-3995 & 97 & BD-6019 \\
\hline 48 & BD-4009 & 98 & BD-6020 \\
\hline 49 & BD-4010 & 99 & BD-6021 \\
\hline 50 & BD-4013 & 100 & BD-6022 \\
\hline
\end{tabular}

\subsection{Assessment of Stemphylium blight}

Disease severity data was recorded in three times on the basis of 0-5 scale where, $0=$ No infection (HR), $1=$ Few scattered leaf but no twig blighted (R), $2=5-10 \%$ leaflets infected and/or few scattered twig blighted (MS), $3=11-20 \%$ leaflets infected and/or 1-5\% twig blighted (MS), $4=21-50 \%$ leaflet infected and/or 6-10\% twig blighted (S) and $5=$ above $51 \%$ leaflet infected and/or more than $10 \%$ twig blighted (HS) $[8,9]$.

\section{$2.4 \quad$ Weather data}

The weather of the experimental site during the study period was collected from the Meteorological Department, Barisal, Bangladesh.

Table 2: The minimum and the maximum temperature and relative humidity as well as mean rainfall at Regional Agricultural Research Station (RARS), BARI, Rahmatpur, Barisal

\begin{tabular}{|l|l|l|l|l|l|}
\hline \multirow{2}{*}{ Month } & \multicolumn{2}{|l|}{ Temperature $\left({ }^{\circ} \mathrm{C}\right)$} & \multicolumn{2}{l|}{ Relative Humidity (\%) } & $\begin{array}{l}\text { Rainfall } \\
(\mathrm{mm})\end{array}$ \\
\cline { 2 - 5 } & Max & Min & Max & Min & \\
\hline November 2011 & 29.38 & 19.63 & 94.56 & 50.63 & 0.00 \\
\hline December 2011 & 24.26 & 15.52 & 96.32 & 57.06 & 0.00 \\
\hline January 2012 & 23.81 & 15.58 & 86.35 & 51.52 & 22.20 \\
\hline February 2012 & 28.17 & 18.62 & 82.21 & 34.66 & 0.00 \\
\hline March 2012 & 32.45 & 22.81 & 95.32 & 44.77 & 0.00 \\
\hline April 2012 & 32.37 & 24.37 & 94.13 & 59.90 & 144.00 \\
\hline
\end{tabular}

Source: Metrological Department. Barisal, Bangladesh

\section{$2.5 \quad$ Data analysis}

MSTAT-C program was used to analyze the collected data. ANOVA as well as LSD test were done to determine the huge variation among the treatment means. 


\section{RESULT}

\subsection{Disease Reaction of Stemphylium Blight of lentil}

\subsubsection{Flowering stage}

The lentil lines/varieties were evaluated for their reaction to Stemphylium blight under natural epiphytotic condition during the winter season of 2011-12 and showed significant difference in reaction to Stemphylium botryosum (Figure 1). In flowering stage, out of 100 lines/varieties 5, 91 and 6 lines/varieties were showed Highly Resistant (HR), Resistant (R) and Moderately Resistant (MR) reaction. In this stage 5 lines viz. BD-3921, BD-3930, BD-3931, BARI masur-7 and Local check in the flowering stage (Figure 2).

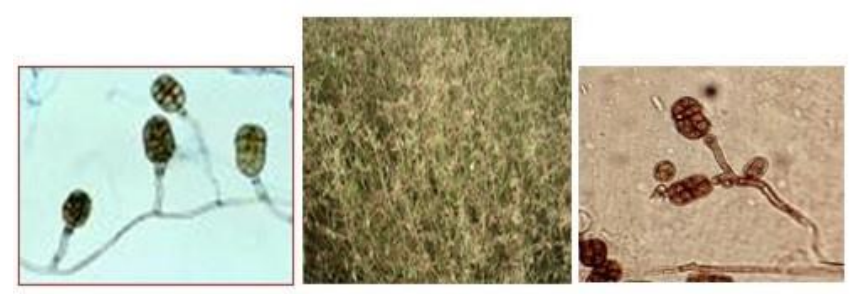

Figure 1: Conidia and conidiophores of Stemphylium botryosum of lentil
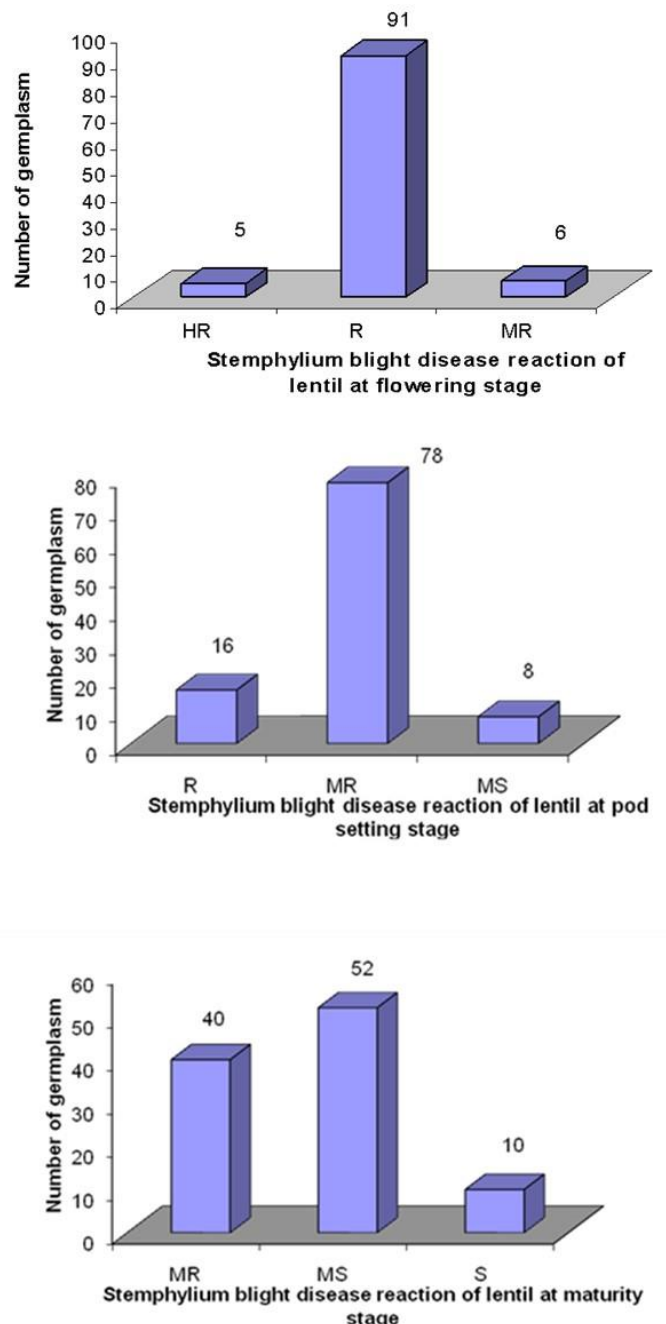

Figure 2: Stemphylium blight disease reaction of selected lentil lines/varieties at flowering stage, pod setting stage and maturity stage.

\subsubsection{Pod setting stage}

The lentil lines/varieties were showed wide variation in reaction to $S$. botryosum in pod formation stage. Out of 102 lines/varieties, 16, 78 and 8 lines were showed Resistant (R), Moderately Resistant (MR) and Moderately Susceptible (MS) reaction in the pod setting stage respectively (Figure 2). The resistant 16 lines were BD-3929, BD-3930, BD-3931, BD-
3932, BD-3936, BD-3938, BD-3941, BD-3963, BD-3965, BD-3980, BD3981, BD-3983, BD-3984, BD-3984, BARI masur-7 and Local check.

\subsubsection{Maturity stage}

In this stage, lentil lines/varieties were showed wide variation in reaction to Stemphylium botryosum. Among 102 lines/varieties, 40, 52 and10 lines were expressed Moderately Resistant (MR), Moderately Susceptible (MS) and Susceptible (S) response respectively (Figure 2). The moderately resistant 40 lines were selected for yield and yield contributing characters (Plate no.2-7).

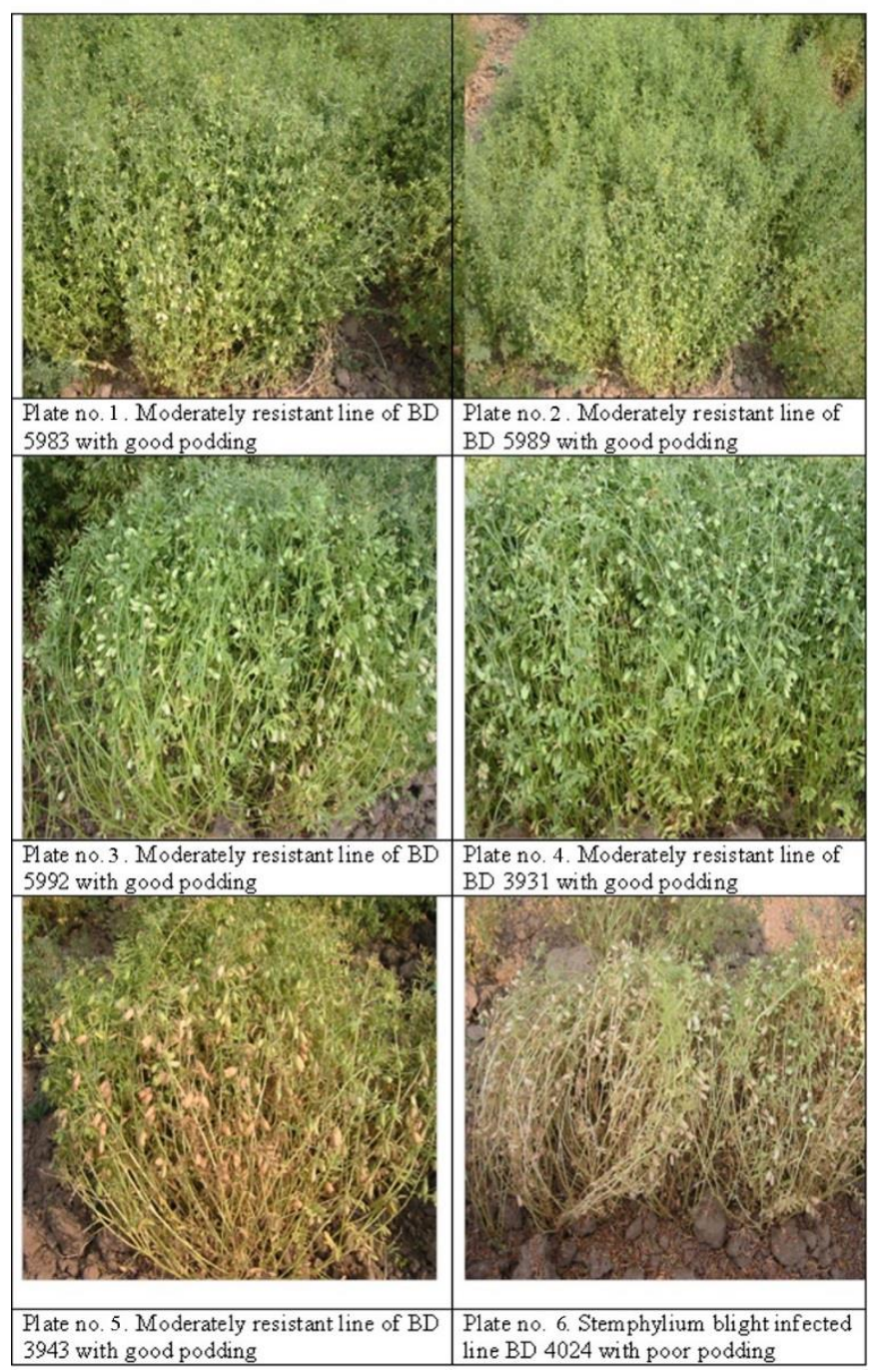

Figure 3: Several pictures of lentil in plate

\section{DISCUSSION}

During last two decades Stemphylium blight lentil caused by Stemphylium botryosum have emerged as devastating pathogen in Bangladesh. It is considered prime limiting factor in lentil production in our country causing huge economic losses and threatening lentil production. The present research was carried out to screen different lentil lines/varieties under natural epiphytotic condition against stemphylium blight in the southern region of Bangladesh. The tested lentil lines/varieties exhibited broad variation in reaction to Stemphylium blight during different growth stage under field condition. The sensitivity tendency of prevalence of Stemphylium was flowering stage $>$ pod setting stage $>$ maturity stage i.e. increased with age of plants. However, all the lines/varieties were not followed the same pattern. Few lines/varieties showed sensitivity during flowering stage [10]. Besides, the lines/verities which are tested showed variation in tolerance/resistance in research period. These findings justify other researchers' findings. Bakr and Ahmed (1993) study on 110 genotypes and found only one genotype resistant to Stemphylium blight and 11 genotypes were tolerant [7]. Beare (2002) screened lentil lines/varieties against Stemplylium blight under natural condition and 
obtained some lines/varieties as moderately resistance and susceptible [11]. Present research findings disclosed that the tested lentil lines/verities exhibited several reaction to Stemphylium blight in field condition. There are two (2) reasons behind the variation among tested lentil lines/ varieties in three (3) different stages regarding disease reaction. One is the genetic variation which controls the resistance mechanism of plant against Stemphylium blight and another is pathogenic strain/races alteration of $S$. botryosum since some materials showed resistant creation, these may be due to exposure of different resistant mechanism of plant. A study reported that the resistance was found to have a thicker cuticle, thickens epidermal cell layer, thicker cuticle layer, fewer stomata and a large number of epidermal hairs compared to the susceptible lines [12]. This result agrees with some study [13-15]. From this study it is clear that none of the tested materials were immune to $S$. botryosum. A group researchers also did not find any material immune lines/verities to $S$. botryosum $[4,11,16-18]$. These experiments elicited that temperature, leaf wetness and relative humidity $(\mathrm{RH})$ are the major environmental factors influencing the development of the disease [19]. The surveys and field experiment in India and Bangladesh on S. botryosum, have confirmed the necessity of temperature and RH for developing of Stemphylium blight in lentil [20]. Species of Stemphylium may occur a wide range of environmental conditions [19-21] investigated the reason behind the periodic appearance, every 2-4 years of Stemphylium blight of lentil in Bihar, India. Different surveys were also conducted in several locations from December to February 1986-90. Average temperature of $18 \pm 2^{\circ} \mathrm{C}$ and morning relative humidity of $85-90 \%$ appeared to be favourable for the appearance, development and spread of the disease, while afternoon $\mathrm{RH}>50 \%$ was essential. An average 7.7 hours of sunshine was favorable but form $>8$ hours was unfavorable. Number of cloudy and foggy days was most responsible factor in determining the appearance and development of the disease, which was between 30 and 40 days in the favorable years and between 17 and 23 days in unfavorable years. Regarding the findings of the present study it may be concluded that the materials of lentil that showed resistant reaction in November-2011 to April-2012 to $S$. botryosum need to be tested for furthers conformation of the result of this study.

\section{CONCLUSION}

Stemphylium botryosum which is responsible for Stemphylium blight of lentil is considering at present as one of the most responsible constrains of lentil production in Bangladesh. Under the present study seeds of 102 lentil varieties/lines were evaluated for their reaction to Stemphylium blight under natural epiphytotic conditions in the southern region of Bangladesh.

During the experimental period of 2011-12 under field condition it was observed that, out of 102 lines/varieties 5, 91 and 6 lines/varieties were exhibited Highly Resistant (HR), Resistant (R) and Moderately Resistant (MR) reaction in flowering stage respectively. In this stage 5 lines which showed Highly Resistant (HR) are BD-3921, BD-3930, BD-3931, BARI Masur-7 and Local check. But out of 102 lines/varieties, 16, 78 and 8 lines were showed Resistant (R), Moderately Resistant (MR) and Moderately Susceptible (MS) reaction in the pod setting stage and 40 lines/varieties were graded as moderately resistance where 52 and 10 were recorded as moderately susceptible and susceptible at maturity stage.

The tested lentil lines/verities differed significantly from one to another in respect of growth and yield contributing parameters. During the year 2011-12 performance of plants were very good in 40 lines/varieties which were screened from 102 lines/varieties where 52 are moderately susceptible and 10 are susceptible in maturity or final stage.

\section{REFERENCES}

[1] BBS. 2012. Yearbook of Agricultural Statistics of Bangladesh. Bangladesh Bureau of Statistics, Statistics Division, Ministry of Planning, Government of People's Republic of Bangladesh, Dhaka.

[2] Anjum. 2005. Evaluation of Lentil genotypes for resistance to pea seed borne mosaic virus. International Journal of Agriculture and Biology, 7, 1.

\section{[3] FAOSTAT. 2002. http://www.fao.org/faostat/en/}

[4] Bakr, M.A. 1993. Plant protection of lentil in Bangladesh. In Erskine, W and Saxena, M. C. (eds). Lentil in South Asia, Proceedings of the Seminar on lentil South Asia, 11-15 March 1991, New Delhi, India, ICARDA, Aleppo, Syria. Pp. 236.

[5] Erskine, W., Sarker, A. 1997. Bangladesh in a big way and the results has been satisfying. ICARDA has been helping breed the varieties of the future. ICARDA Caravan, 6 (6), 8-10.

[6] Anonymous. Competitor Moulds and Diseases in Mushroom Production.

http://agridaksh.iasri.res.in/html_file/mushroom/competitor_moulds_a nd_diseases_i.htm

[7] Bakr, M.A., Ahmed, F. 1993. Integrated management of Stemphylium blight of lentil. Abst. No. 3.5.47. Presented in the 6th Intl. Congress of Plant Pathology held in Montreal, Canada, 28 July-6 August p.361.

[8] Bakr, M.A., Ahmed, F. 1992. Development of Stemphylium blight on lentil and its chemical control. Bangladesh Journal of Plant Pathology, 8, $39-40$.

[9] Salam, M.U., Day, T.K., Ahmed, A.U., Nessa, B., Haque, A.H.M.M., Subedi, S., Malik, A.I., Rahman, M.M., Erskine, W. 2016. Stempedia: a weatherbased model to explore and manage the risk of lentil Stemphylium blight disease. Australasian Plant Pathology, 45, 499.

[10] Mondol, M.E.A., Rahman, H., Rashid, M.H., Hossain, M.A., Islam, M.M. 2013. Screening of mungbean germplasm for resistance to Mungbean Yellow Mosaic Virus. International Journal of Sustainable Crop Production, 8 (1), 11-15.

[11] Beare, M. 2002. Investigation into Stemphylium botryosum resistance in lentil. Undergraduate thesis. University of Saskatchewan. Canada.

[12] Chowdhury, A.M., Ahmed, A., Zaman, M. 1997. Studies on the defense structural factors of some susceptible and resistant varieties of lentil plants. Mycological Research, 35, 35-39.

[13] Singh, A.K., Chowdhury, S.L. 1982. A note on weed control in rabi pulses with pre-emergence and pre-planting herbicides. Indian Journal of Agronomy, 15 (3), 252-253.

[14] Mia, M.Z., Mian, M.A.K., Rahman, M.M. 1986. Performance of exotic lentil germplasm in Bangladesh. LESs Newsletter, 13 (2), 12-13.

[15] Bakr, M.A. 1994. Check list of pulse dis. in Bangladesh. Journal of Plant Pathology, 10 (1-2), 13-16.

[16] Ahmed, H.U., Bakr, M.A., Alam, K.B. 1981. Pathogen survey of major winter and summer pulses in Bangladesh. Pro National workshop on pulses. BARI. Joydebpur during 18-19.

[17] Bayaa, B., Erskine. 1998. Diseases of lentil. In: The Pathology of Food and Pasture legumes. Edited by D. J. Allen, and J. M. Lenne, Pp 473.

[18] Francovig, P.C., Mehta, Y.R., Fonseca, N.S., Reis, M. 1999. Sources of resistance to Stemphylium solani in cotton cultivars. Summa Phytopathologica, 25 (3), 217-222.

[19] Basallote- Ureba, M.J., Prados-Ligero, A.M., Melero-Vara, J.M. 1999. Aetiology of leaf spot of garlic and onion caused by Stemphylium vesicarium in Spain. Plant Pathology, 48 (1), 139-145.

[20] Sinha, J.N., Sing, A.P. 1993. Effect of environment on the development and spread of Stemphylium blight of lentil. Indian Phytopathology, 46 (3), 252-253.

[21] Suheri, H., Price, T.V. 2000. Stemphylium leaf blight of garlic (Allium sativum) in Australia. Australasian Plant Pathology, 29 (3), 192-199.

[22] Diary, K. 2012. Agriculture Information Service. Ministry of Agriculture. Govt. Peoples Republic of Bangladesh 